\title{
Effect of decalcifying agents on the staining of Mycobacterium tuberculosis
}

\author{
G. ANDERSON AND A. J. COUP
}

From the Department of Pathology, The Royal Hospital, Sheffield and Academic Division of Pathology, University of Sheffield

SYNOPSIS Lymph nodes from guinea pigs inoculated with Mycobacterium tuberculosis were fixed in buffered formalin, then treated for the recommended times in Gooding and Stewart's fluid, EDTA, aqueous nitric acid, von Ebner's fluid, and rapid decalcifier (RDC). The blocks were processed to paraffin wax and sections were stained by the Ziehl-Neelsen technique. Only in sections of the blocks treated with RDC were no acid alcohol fast bacilli demonstrable.

Hydrochloric acid is a known constituent of RDC and it was found that Myco. tuberculosis is altered by treatment with $2 \cdot 5 \mathrm{M}$ solutions of hydrochloric acid and above and cannot subsequently be demonstrated by the Ziehl-Neelsen stain.

From these results it is recommended that calcified tissue from patients in whom there is a suspicion of tuberculosis should be decalcified with an agent other than RDC.

Rapid decalcifier (RDC) ${ }^{1}$ is used in this laboratory for rapid routine decalcification of tissues before processing for histology. It was noted in a calcified cervical lymph node, showing the histological features of a tuberculous lymphadenitis, that after decalcification with this agent no acid and alcohol fast bacilli (AAFB) could be demonstrated in sections using the Ziehl-Neelsen technique. It was thought that RDC might impair the staining of Mycobacterium tuberculosis with carbol fuchsin.

\section{Material and Methods}

Lymph nodes from guinea pigs inoculated with Myco. tuberculosis were fixed in buffered formalin and processed to paraffin wax to act as a control, while other blocks were fixed and then treated for the recommended times in Gooding and Stewart's fluid, EDTA, aqueous nitric acid, von Ebner's fluid, and RDC (Culling, 1974). These blocks were then processed to paraffin wax. Other blocks treated with these agents were neutralized in $0.5 \mathrm{M}$ sodium sulphate overnight, then washed in running tap water for a further six hours before processing to paraffin wax.

Three sections from each block were stained by the Ziehl-Neelsen technique (Culling, 1974) and examined independently by both of us.

Received for publication 4 March 1975.

${ }^{1}$ RDC, Bethlehem Instrument Ltd, Hemel Hempstead.

\section{Results}

Only in sections of the blocks treated with RDC were no AAFB demonstrable by the Ziehl-Neelsen tech nique; the bacilli in these sections were, however; stained with the methylene blue counterstain, showing that no basophilia had been lost.

Although the precise formula of RDC is uncertain, it is known that hydrochloric acid is a constituent. Therefore, RDC was diluted $1: 10$ with distilled water, and $10 \mathrm{ml}$ aliquots were titrated against $0 \cdot 1 \mathrm{M}$ sodium hydroxide using methyl orange indicator. The concentration of hydrochloric acid was found to be $4.06 \mathrm{M}$. As von Ebner's fluid contains $0 \cdot 152 \mathrm{M}$ hydrochloric acid and AAFB were demonstrable in tissue treated with this agent. further blocks were treated with a range of hydrochloric acid solutions for four hours. After treatment with solutions of $2 \cdot 5 \mathrm{M}$ hydrochloric acid and above, no AAFB could be demonstrated.

A section from the control block was stained with hot carbol fuchsin, decolourized with RDC, and then counterstained with methylene blue. AAFB were stained, showing that RDC cannot alter the nature of these bacilli once they have been stained with carbol fuchsin.

\section{Conclusions}

Myco. tuberculosis is irreversibly altered by treatment with $2 \cdot 5 \mathrm{M}$ solutions of hydrochlo ric acid and 
above and cannot subsequently be demonstrated by the Ziehl-Neelsen stain.

Calcified lymph nodes are not uncommonly examined histologically in cases of suspected tuberculosis. From the results of the above experiments we would recommend that tissue from patients in whom there is a suspicion of this diagnosis should be decalcified with an agent other than RDC.
Thanks are due to Dr D Harris who kindly supplied lymph nodes from tuberculous guinea pigs.

\section{Reference}

Culling, C. F. A. (1974) Handbook of Histopathological and Histochemical Techniques, 3rd edition. Butterworth, London.

\section{The August 1975 Issue}

\section{THE AUGUST 1975 ISSUE CONTAINS THE FOLLOWING PAPERS}

Differentiation of porphyria cutanea tarda symptomatica from other types of porphyria by measurement of isocoproporphyrin in faeces G. H. ELDER

A comparative study of serum total thyroxine estimation on unextracted serum by radioimmunoassay and by competitive protein binding PHILIP MARSDen, PAUl FACER, MANuel acosta, AND P. J. N. HOWORTH

Adult $\alpha_{1}$-antitrypsin deficiency E. C. SWEENEY

Asymptomatic liver disease in haemophiliacs P. M. MANNUCCI, ANNA CAPITANIO, E. DEL NINNO, M. COLOMBO, F. PARETI, AND Z. M. RUGGERI

Measurement of plasma renin activity by semimicro radioimmunoassay of genərated angiotensin I M. J. DILLON

Immunochemical studies of the endocrine cells of the gastrointestinal tract. II. An immunoperoxide technique for the localization of secretin-containing cells in human duodenum GRAHAM ROBINSON AND IAN DAWSON

Quantitation of G-cells in fibreoptic biopsy specimens and serum gastrin levels in healthy normal subjects J. PIRIS AND R. WHITEHEAD

Ultrastructure of cell migration through the gastric epithelium and its relationship to bacteria H. W. STEER
Adenoid cystic carcinoma of the breast: prevalence, diagnostic criteria, and histogenesis P. P. ANTHONY AND P. D. JAMES

A histochemical method of differentiating lower gastrointestinal tract mucin from other mucins in primary or metastatic tumours C. F. A. CULliNG, P. E. REID, J. D. BURTON, AND W. L. DUNN

Muscle fibre type changes in hypothyroid myopathy R. O. MCKERAN, G. SLAVIN, T. M. ANDREWS, P. WARD, AND W. G. P. MAIR

Some observations on cooling in laboratory autoclaves P. H. EVERALL AND C. A. MORRIS

Elution patterns of rubella IgM, IgA, and IgG antibodies from a dextran and an agarose gel J. R. PATTISON AND JENNIFER E. MACE

The cytocentrifuge NBT test P. A. GORDON, J. STUART, T. R. LEE, G. R. BREEZE, AND R. N. H. PUGH

An evaluation of some commercial Romanowsky stains P. N. MARSHALL, S. A. BENTLEY, AND S. M. LEWIS

\section{Technical method}

A rapid method for identifying bacterial enzymes J. L. MADDOCKS AND MARY JO GREENAN

Letters to the Editor

Book reviews

Copies are still available and may be obtained from the PUBLISHING MANAGER, British medical association, tavistock sQuare, London, wc1h 9JR, Price $£ 2 \cdot 00$ 